WOLF SCHLUCHTER

\title{
Life cycle sustainability assessment of municipal waste management systems
}

Prof. Wolf Schluchter Brandenburg University of Technology in Cottbus - Germany, Faculty of Environmental Sciences and Process Engineering, Chair of Environmental Issues in Social Sciences

Ph.D. Magdalena RybaczewskaBłażejowska Kielce University of Technology, Faculty of Management and Computer Modelling, Chair of Production Engineering

\section{Introduction}

The existing waste legislation, including the Waste Framework Directive 2008/98/ $\mathrm{EC}$, requires thorough rethink of the applied municipal waste management practices. Currently, all EU Member States "shall take into account the general environmental protection principles of precaution and sustainability, technical feasibility and economic viability protection of resources as well as the overall environmental, human health, economic and social impacts" while managing their waste (Directive 2008/98/EC). This explicitly shows that environmentally, economically and socially sustainable waste management systems that offer the integration of waste management options (collection and treatment methods) became not only Polish, but also a global necessity. Only the interrelationship of these three crucial elements of sustainability makes the municipal waste management systems truly responsible for current and future generations.

The trade-off between environmental performance, economic aspects and social 
issues can be attained by the application of multi-criteria decision instruments (MCDA). One of such tools is the comprehensive Life Cycle Assessment (LCA) that originally was applied for the assessment of the environmental aspects and potential impacts associated with a particular product or process throughout its life cycle. Following a series of international standards for LCA, particularly ISO 14040:2006 and ISO 14044:2006, the LCA methodology covers goal and scope definition, Life Cycle Inventory (LCI) - an inventory of relevant inputs and outputs of a product or process system, Life Cycle Impact Assessment (LCIA) - an evaluation of the potential environmental impacts associated with these inputs and outputs and finally the interpretation of the results of the inventory analysis and impact assessment phases in relation to the objectives of the research (Barański 2011). Nowadays the technique of LCA is very often complemented by the costs analysis (LCCA), including conventional and societal costs (Kowalski et al. 2007).

This article refers to the authors" research on "The application of life cycle assessment in the integrated municipal waste management" founded by DAAD (Deutscher Akademischer Austauschdienst). The aim of the research was to elaborate a universal decision support instrument allowing the sustainability assessment of the waste collection, transportation and sorting strategy for a given specific circumstances. This article discusses the assessment criteria to measure environmental, economic and social sustainability of alternative scenarios for municipal waste collection, transportation and sorting. The data gathered by the authors during the research has both theoretical and practical contribution to current knowledge. On the one hand, it rectifies the general scarcity of literature resources devoted to the application of life cycle assessment in municipal waste management. On the other hand, it has significance to practitioners by helping them to make a decision on responsible municipal waste management based upon the life cycle sustainability assessment.

\section{LCA model of municipal waste management systems}

Life cycle assessment (LCA) model of municipal waste management system was made by splitting the whole system into two major subsystems - collection and treatment (see figure 1). The latter - physical, biological and chemical transformation of municipal waste makes the background system of this study. The research was based upon the assumption that all EU Member States while choosing the waste treatment method follow the waste hierarchy of Directive 2008/98/EC and thus try to apply reuse and recycling prior energy recovery 


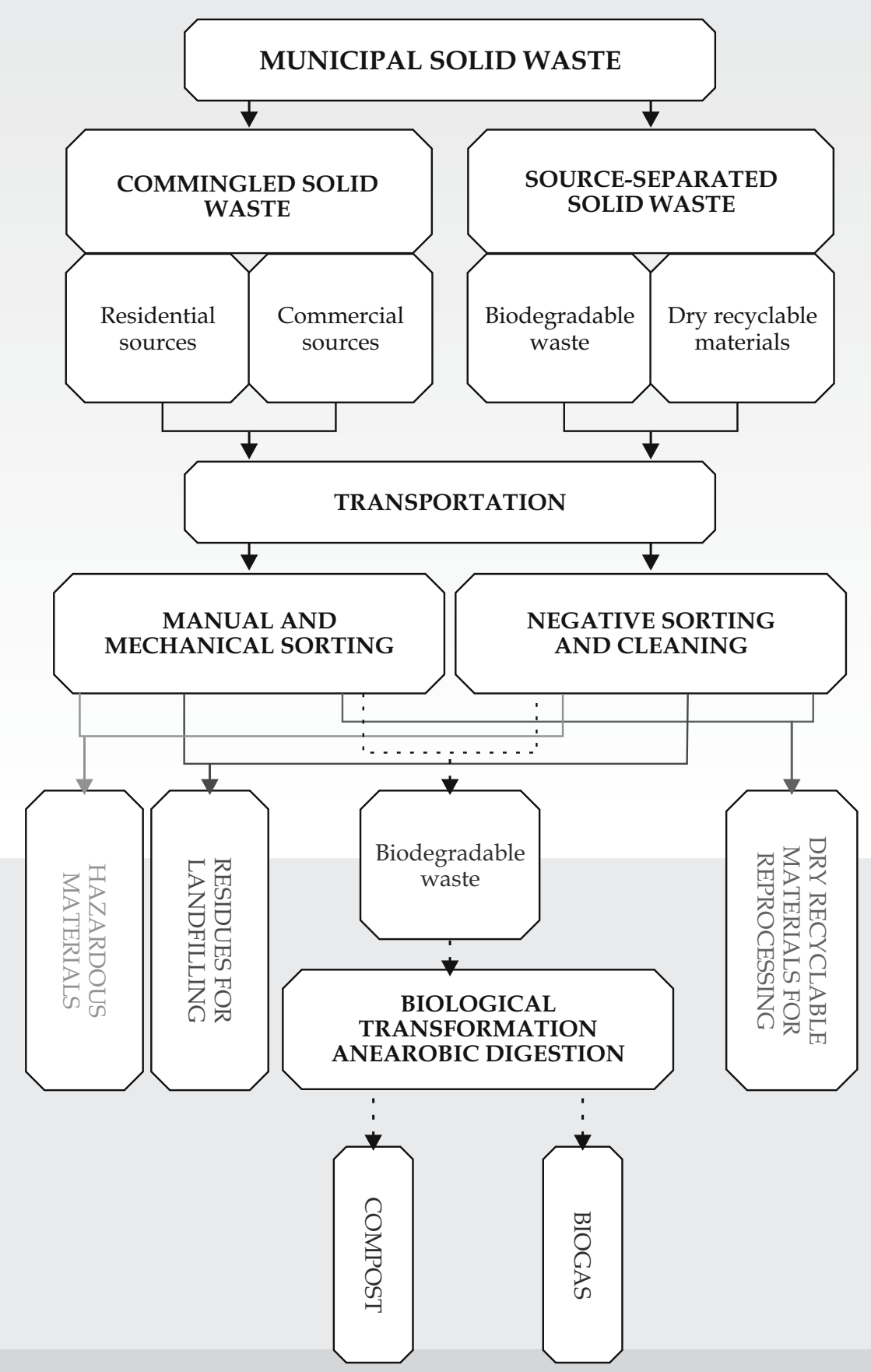

Figure 1. Sample flowchart of municipal waste management system Source: own study 
and disposal. The hierarchy order is caused by encouragement to use such options for waste management that "deliver the best overall environmental outcome" (Directive 2008/98/EC).

The foreground system of this research makes the subsystem of municipal waste collection built of various individual processes selected for modeling of the integrated municipal waste management. These are municipal waste collection itself (being sometimes defined as the temporary storage), transportation from collection points to a materials recovery facility (MRF) and the operation of MRF where waste are subjected to manual sorting and/or mechanical processing. Consequently, this LCA analysis starts at the moment waste is disposed of in a bin, a bag or a container and completes with acquiring materials ready to reuse or recycling (see figure 2). Selection of the collection - transportation - sorting alternatives was based upon a state-of-the-art in municipal waste management in the European Union. It ought to be emphasized that the design of the collection subsystem has a direct influence on the subsequent physical, biological and chemical processing operations of waste and thus plays a decisive role in the successful functioning of the whole system of municipal waste management (White 1996).

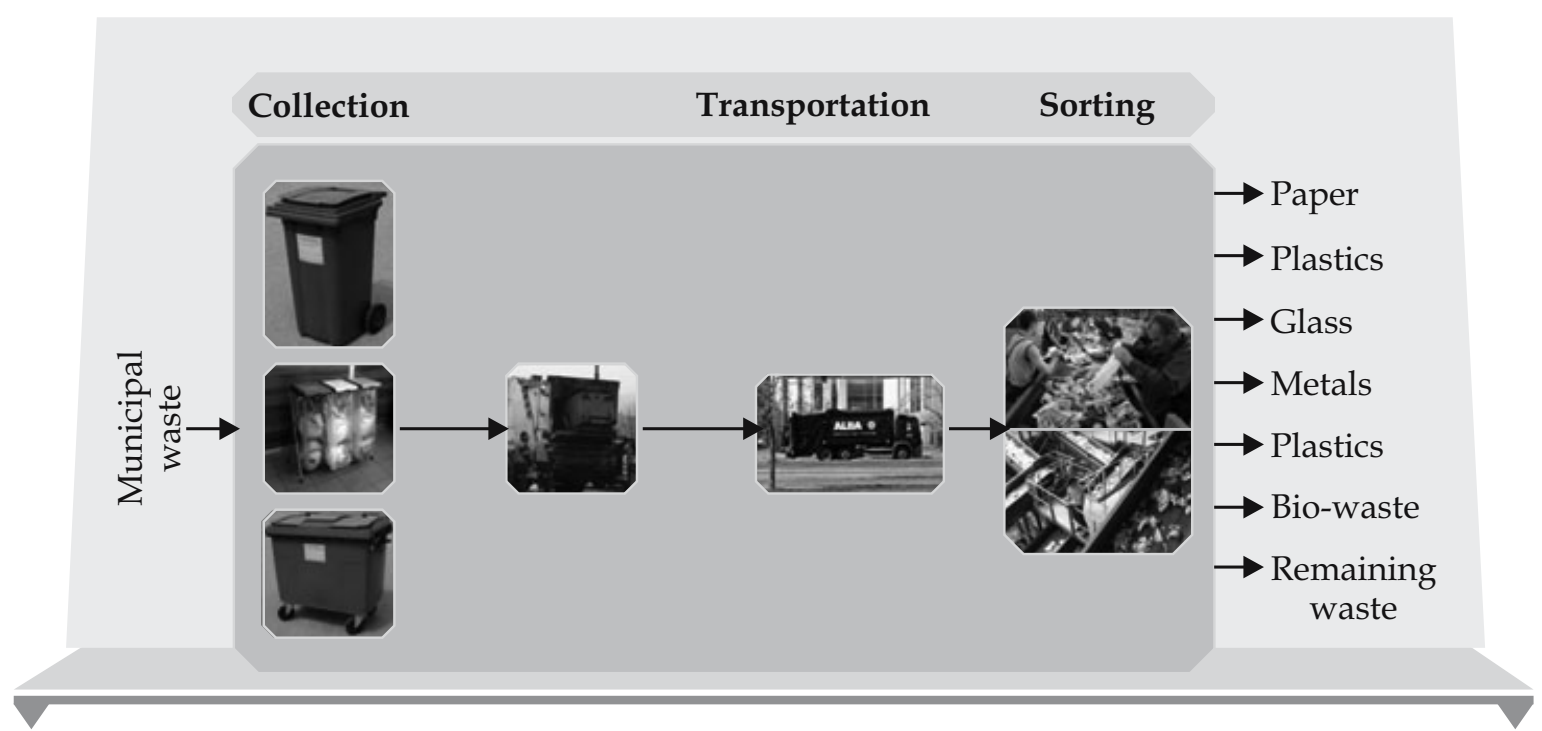

Figure 2 . The boundaries of the life cycle sustainability assessment analysis Source: own study 


\section{Life cycle sustainability assessment of municipal waste collection - transportation - sorting}

Life cycle sustainability assessment of municipal waste collection transportation - sorting was based upon the following assumptions:

- environmental sustainability in municipal waste management was defined through two major objectives, which are conservation of resources and reduction of environmental pollution (Den Boer 2007),

- economic sustainability in municipal waste management was defined as such integration of waste management options as to operate them at the lowest possible cost - acceptable to the community, local government and a municipal waste treatment facility itself,

- social sustainability in municipal waste management was defined as provision of appropriate level of waste services to meet health and comfort requirements of participants.

Below direct environmental, economic and social categories were recognised for all major alternatives of the collection-transportation-sorting modules of municipal waste management (see table 1, 2 and 3). Methodology for their calculation can be found in the relevant literature (see examples below). Crucial indirect aspects of the foreground system (municipal waste collection) are those related with environmental, economic and social benefits of gathered recyclable materials (either through collection or sorting).

\subsection{Module of municipal waste collection}

Considering the stage of municipal waste collection, it usually involves a combination of commingled waste collection and source-separated waste collection. The applied solutions differs, however, considerably since several alternatives for waste collection are available. Decision has to be made on grouping the individual streams of waste, the type and location of waste containers, and finally the manner and frequency of collection (Rhyner et al. 2000) (see figure 3). 


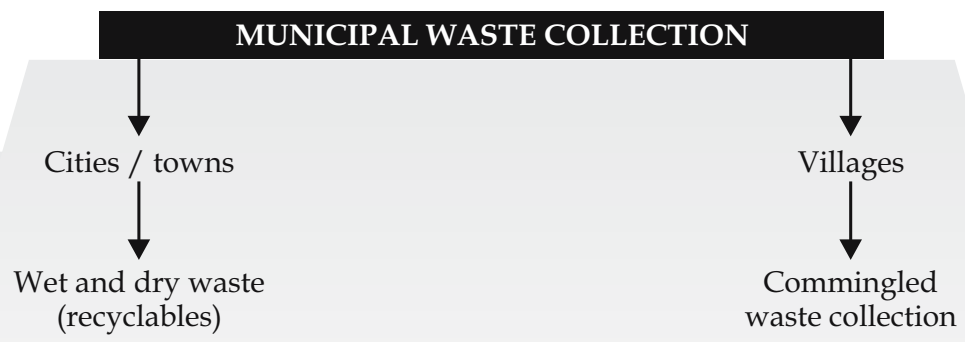

Separate collection of paper, plastics, glass, organic waste und residual waste

Kerbside collection (bags 120/2401)

Separate collection of paper, plastics, glass, organic waste und residual waste

Bring system (containers 660/11001)

Weekly or fortnightly collection

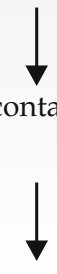

Fortnightly or monthly collection

Figure 3. Alternatives for municipal waste collection

Source: own study on Rhyner et al. 2000

Table 1. Environmental, economic and social criteria for municipal waste collection

\begin{tabular}{|c|c|c|c|}
\hline $\begin{array}{l}\text { Collection } \\
\text { alternatives }\end{array}$ & Environmental aspects & Economic aspects & Social aspects \\
\hline $\begin{array}{c}\text { Commingled } \\
\text { waste collection }\end{array}$ & $\begin{array}{l}\text { Emissions of container or } \\
\text { bin production (including } \\
\text { the type of material } \\
\text { applied) } \\
\text { Recycling rate after } \\
\text { disposal of container } \\
\text { or bin }\end{array}$ & $\begin{array}{l}\text { Capital investment } \\
\text { for containers or bins } \\
\text { End of life costs of } \\
\text { containers or bins } \\
\text { Annual maintenance } \\
\text { costs }\end{array}$ & $\begin{array}{l}\text { Convenience of use } \\
\text { Odour } \\
\text { Public or private space } \\
\text { consumption (land } \\
\text { use) } \\
\text { Visual impact }\end{array}$ \\
\hline $\begin{array}{l}\text { Source-separated } \\
\text { waste collection }\end{array}$ & $\begin{array}{l}\text { Emissions of container, bin } \\
\text { or bag production including } \\
\text { the type of material } \\
\text { applied) } \\
\text { Recycling rate after disposal } \\
\text { of container, bin or bag }\end{array}$ & $\begin{array}{l}\text { Capital investment } \\
\text { for containers (the } \\
\text { bring system) or bins } \\
\text { and bags (the kerbside } \\
\text { system) }\end{array}$ & $\begin{array}{l}\text { Convenience of use } \\
\text { Odour } \\
\text { Public space } \\
\text { consumption (the } \\
\text { bring system) }\end{array}$ \\
\hline
\end{tabular}


Conservation of resources through the collection of secondary raw materials Exploitation of natural resources (water) for the preparation of sourceseparated waste
End of life costs of containers, bins or bags

Annual maintenance costs
Private space consumption (the kerbside system)

Visual impact

Source: own study

Sample equation for the calculation of the total annual amount of required material for container production (Den Boer (Szpadt) et al. 2005):

$$
\mathrm{YMCP}_{\mathrm{i}}=\frac{\sum \mathrm{NTFU}_{\mathrm{i}, \mathrm{j}} \mathrm{x}(1+\mathrm{EBNS}) \times \mathrm{CoWe}_{\mathrm{i}, \mathrm{j}} \times\left(100 \%-\mathrm{RRUC}_{\mathrm{i}}\right)}{\mathrm{LiTi}_{\mathrm{i}, \mathrm{k}}}
$$

$\mathrm{YMCP}_{1}$ - Yearly amount of material needed for container production for material i [kg/year],

$\mathrm{NTFU}_{\mathrm{i}, \mathrm{j}}$ - Total of TS which are finally used for container of material $\mathrm{i}$ and main TS type $\mathrm{k}$ [no.],

EBNS - Extra containers needed in stock for smooth operation [\%],

$\mathrm{CoWe}_{\mathrm{i}, \mathrm{j}}$ - Container weight for containers of material i with volume $\mathrm{j}[\mathrm{kg}]$,

RRUC $_{1}$ - Recycling rate of used containers for material i [\%],

$\operatorname{LiTi}_{\mathrm{i}, \mathrm{k}}$ - Life time for container of material $\mathrm{i}$ and main TS type $\mathrm{k}$ [year].

\subsection{Module of municipal waste transportation}

Transportation covers the haulage of municipal waste in a collection vehicle from the collection district to the materials recovery facility (MRF). Basically, there are two possibilities of organising municipal waste eco-logistics, which are the collection and direct transportation to MRF or the collection and re-loading at the transfer station prior to transportation to MRF. Operating (cost) efficiency is a decisive factor that has to be answered on a case-by-case basis, whether to apply a direct haul or a bulk transport via the transfer station. Most experts suggest, however, that transfer stations are difficult to justify unless the distance is in the range of 16-24 kilometers. 
Table 2. Environmental, economic and social criteria for municipal waste transportation

\begin{tabular}{l|l|l|l}
\hline $\begin{array}{l}\text { Transportation } \\
\text { alternatives }\end{array}$ & \multicolumn{1}{|c|}{$\begin{array}{c}\text { Environmental } \\
\text { aspects }\end{array}$} & \multicolumn{1}{|c}{ Economic aspects } & Social aspects \\
\hline $\begin{array}{l}\text { Collection } \\
\text { and direct } \\
\text { transportation to } \\
\text { MRF }\end{array}$ & $\begin{array}{l}\text { Fuel consumption } \\
\text { Air emissions } \\
\text { deriving from fuel } \\
\text { consumption } \\
\text { Noise }\end{array}$ & $\begin{array}{l}\text { Investment costs for vehicles for } \\
\text { waste transportation (truck fleet) } \\
\text { Annual maintenance costs of vehicles } \\
\text { End of life costs of vehicles } \\
\text { Fuel costs } \\
\text { Personnel employment costs }\end{array}$ & $\begin{array}{l}\text { Noise } \\
\text { Odour } \\
\text { Traffic nuisance } \\
\text { Employment } \\
\text { creation (work } \\
\text { places) }\end{array}$ \\
\hline $\begin{array}{l}\text { Collection } \\
\text { and re-loading } \\
\text { at the transfer } \\
\text { station prior to } \\
\text { transport to MRF }\end{array}$ & $\begin{array}{l}\text { Fuel consumption } \\
\text { Air emissions } \\
\text { ceriving from fuel } \\
\text { consumption } \\
\text { Eoise } \\
\text { transsions of the } \\
\text { operation }\end{array}$ & $\begin{array}{l}\text { Investment costs for vehicles for } \\
\text { waste transportation (truck fleet) } \\
\text { Annual maintenance costs of vehicles } \\
\text { End of life costs of vehicles } \\
\text { Fuel costs } \\
\text { Investment costs for the construction } \\
\text { of the transfer station } \\
\text { Annual maintenance costs of the } \\
\text { transfer station } \\
\text { Personnel employment costs }\end{array}$ & $\begin{array}{l}\text { Noise } \\
\text { Odour } \\
\text { Dust } \\
\text { Traffic nuisance } \\
\text { Employment } \\
\text { creation (work } \\
\text { places) }\end{array}$ \\
\hline
\end{tabular}

In order to meet the requirements of the collection system, the required number and type of vehicles for waste collection and transportation have to be provided. Sample procedure for the calculation of the truck fleet is provided below (d'Obyrn and Szalińska 2005):

$$
S=\frac{M \cdot k_{t}}{M^{\prime} \cdot t}
$$

S - Number of collection vehicles [no.],

M - The number of inhabitants,

$k_{t} \quad$ - Frequency of weekly collection,

$\mathrm{M}^{\prime}$ - Number of inhabitants served by one collection vehicle per day,

$\mathrm{t} \quad$ - Number of working days per week of the collection vehicle crew. 
Having the number and type of collection vehicles, their annual operation costs can be calculated as follows:

$$
K t=n \cdot S \cdot S \text { trans } \cdot O N \cdot K O N
$$

$\mathrm{K}_{\mathrm{t}}$ - Annual operations costs of the collection vehicles [zl/year],

$\mathrm{n}$ - Number of courses throughout the year,

S - Number of collection vehicles,

$S_{\text {trans }}$ - Transport length,

ON - Fuel consumption,

$\mathrm{K}_{\mathrm{ON}}$ - Fuel costs.

\subsection{Module of municipal waste sorting}

Once municipal waste is collected, it requires further processing to prepare it to recycle. The waste processing is done in materials recovery facilities (MRFs) that might comprise of just a few unit operations in case of handling source-separated municipal waste or many unit operations in case of handling commingled municipal waste. Materials profile of the facility illustrates the degree of sorting varying from level 1 (sorting into the basic components of dry recyclable materials) to level 4 (sorting based upon material type). Although the approach to waste processing might be different, the most commonly applied option is the combined manual and mechanical sorting.

Table 3. Environmental, economic and social criteria for municipal waste sorting

\begin{tabular}{l|l|l|l}
\hline \multicolumn{1}{c|}{$\begin{array}{c}\text { Sorting } \\
\text { alternatives }\end{array}$} & Environmental aspects & \multicolumn{1}{c}{ Economic aspects } & \multicolumn{1}{c}{ Social aspects } \\
\hline $\begin{array}{l}\text { Manual- } \\
\text { mechanical sorting }\end{array}$ & $\begin{array}{l}\text { Electricity } \\
\text { consumption } \\
\text { Lubricants } \\
\text { consumption } \\
\text { Noise } \\
\text { Air emissions of } \\
\text { the sorting facility } \\
\text { operation }\end{array}$ & $\begin{array}{l}\text { Capital investment for } \\
\text { mechanical sorting } \\
\text { technology } \\
\text { Annual maintenance } \\
\text { costs of the sorting facility } \\
\text { Personnel employment } \\
\text { costs }\end{array}$ & $\begin{array}{l}\text { Employment creation } \\
\text { (work places) } \\
\text { Noise } \\
\text { Odour } \\
\text { Dust }\end{array}$ \\
\hline
\end{tabular}

Source: own study 


\section{Conclusions}

Each of the collection - transportation - sorting methods outlined above has its particular characteristics. Consequently, in assessing the most sustainable solution, a number of factors have to be taken into consideration. In the first place, one needs to examine the following issues:

- the type of population (housing) to be served,

- the quantity and composition of waste to be managed,

- the range of recyclable materials to be collected,

- the existing infrastructure for waste collection, transportation and sorting,

- the level of public acceptance and environmental awareness.

Following the life cycle sustainability approach, this list has to be extended, among others, by the assessment of environmental effectiveness (conservation of resources through gathering of secondary raw materials and reduction of environmental pollution), economic affordability and social acceptability. To achieve the compromise between these three is undoubtedly not an easy task since the less effort on the part of citizens, the lower costs of transportation, the higher costs of sorting and the worst quality of dry recyclables and vice versa. Summing up the foregoing, the selection of the reasonable method of collection and transportation for reuse and recycling is a very complex process that needs to be investigated on a case-by-case basis. Authors of this article, upon the above enumerated sustainability criteria, have already done the modeling of municipal waste eco-logistics.

\section{Summary}

Life cycle sustainability assessment of municipal waste management systems

The core element of all waste management systems that determines further treatment is the collection, transportation and sorting of waste. There is a spectrum of options that ranges from the complete source separation of waste with little or no consecutive sorting to the minimum separation at source and the consecutive central sorting of fully commingle waste. As each of the collection - transportation - sorting methods has particular characteristics, in assessing the most sustainable solution, a number of factors have to be taken into consideration. To assist decision makers (ad exemplum local authorities), the authors of this article has specified environmental, economic and social criteria that need to be considered while designing 
the integrated waste management systems. They can be grouped into environmental effectiveness (conservation of resources and reduction of environmental pollution), economic affordability and social acceptability. The article refers to the authors' research on "The application of life cycle assessment in the integrated municipal waste management" founded by DAAD (Deutscher Akademischer Austauschdienst).

Keywords: Life cycle assessment (LCA), municipal waste, eco-logistics, sustainability

\section{Streszczenie}

Słowa

\section{Ocena cyklu życia w gospodarce odpadami komunalnymi}

Kluczowym elementem wszystkich systemów gospodarki odpadami, który warunkuje dalsze zagospodarowanie odpadów jest etap zbiórki, transportu i segregacji tychże odpadów. Istnieje szerokie spektrum możliwości realizacji tego zadania - począwszy od selektywnej zbiórki u źródła i bardzo ograniczonego dalszego sortowania (uzdatniania) a skończywszy na zbiórce odpadów w formie zmieszanej, które następnie poddawane są kompleksowemu sortowaniu i doczyszczaniu. Mając na uwadze fakt, iż każde $\mathrm{z}$ alternatywnych rozwiązań systemu zbiórki - transportu - sortowania odpadów komunalnych wymaga odmiennego podejścia, przy ocenie najbardziej zrównoważonego rozwiązania wiele czynników musi być brane pod uwagę. By pomóc praktykom (na przykład władzom lokalnym) w tym trudnym zadaniu, autorzy niniejszego artykułu określili środowiskowe, ekonomiczne i społeczne kryteria, które powinny być brane pod uwagę podczas projektowania zintegrowanych systemów gospodarki odpadami. Należy wśród nich wymienić efektywność środowiskową (w tym ochronę zasobów naturalnych i zapobieganie zanieczyszczeniom), przystępność ekonomiczną oraz akceptowalność społeczną. Artykuł prezentuje wybrane wyniki badań autorów poświęcone "Zastosowaniu oceny cyklu życia w zintegrowanej gospodarce odpadami komunalnymi" finansowane przez DAAD (Niemiecka Centrala Wymiany Akademickiej).

kluczowe: Ocena cyklu życia (LCA), odpady komunalne, ekologistyka, zrównoważony rozwój 


\section{References}

1. Barański A., Gworek B., Bojanowicz-Bablok A. (2011), Ocena cyklu życia - teoria i praktyka, Instytut Ochrony Środowiska - Państwowy Instytut Badawczy, Warszawa.

2. Directive 2008/98/EC of the European Parliament and of the Council of 19 November 2008 on waste and repealing certain Directives.

3. Den Boer J. (2007), Sustainability Assessment for Waste Management Planning - Development and Alternative Use of the LCA-IWM Waste Management System Assessment Tool - PhD Dissertation, Technische Universität Darmstadt, Darmstadt.

4. Den Boer (Szpadt) E., Den Boer J., Jager J. (2005), The use of life cycle assessment tool for the development of integrated waste management strategies for cities and regions with rapid growing economies LCA-IWM, Technische Universität Darmstadt, Darmstadt.

5. D’Obyrn K., Szalińska E. (2005), Odpady komunalne - zbiórka, recycling, unieszkodliwianie odpadów komunalnych i komunalnopodobnych, Wydawnictwo Politechniki Krakowskiej, Kraków.

6. ISO 14040:2006 Environmental management - Life cycle assessment - Principles and framework.

7. ISO 14044:2006 Environmental management - Life cycle assessment Requirements and guidelines.

8. Kowalski Z., Kulczycka J., Góralczyk M. (2007), Ekologiczna ocena cyklu życia procesów wytwórczych (LCA), Wydawnictwo Naukowe PWN, Warszawa.

9. Rhyner Ch., Schwartz., L Wenger R., Kohrell M. (2000), Waste Management and Resource Recovery, Lewis Publishers, New York.

10. White P. (1996), So what is integrated waste management, Warmer Bulletin 49, Skipton North Yorkshire. 